\title{
ANTOLOGIAS LITERÁRIAS EM LIBRAS
}

\section{ANTOLOGÍAS LITERARIAS EN LIBRAS (LENGUA DE SEÑAS BRASILERA)}

\author{
LITERARY ANTHOLOGIES IN LIBRAS (BRAZILIAN SIGN LANGUAGE)
}

\author{
Rachel Sutton-Spence* \\ Fernanda de Araújo Machado** \\ Anna Luiza Maciel*** \\ Ronice Müller de Quadros ${ }^{* * * *}$ \\ Universidade Federal de Santa Catarina
}

\begin{abstract}
RESUMO: O presente artigo apresenta a constituição de antologias literárias em Libras. Em especial, estará trazendo elementos metodológicos e teóricos que nortearam a criação da Antologia Literária de Libras publicada no Portal de Libras como parte integrante da Documentação de Libras. O objetivo deste artigo é descrever os fundamentos teóricos e práticos no processo de criação de uma antologia de literatura em Libras que poderá servir de referência para futuras antologias literárias em língua de sinais. A antologia integrante do Portal de Libras apresenta 50 exemplos de obras literárias em Libras selecionados de acordo com diversos critérios considerando os usuários que incluem professores, alunos, artistas e pesquisadores. Uma antologia serve como um instrumento para promover literatura em Libras. É por meio de antologias que conhecemos as literaturas do mundo, inclusive das comunidades surdas brasileiras. Neste artigo, apresentamos a origem de tal antologia, o processo de evolução e mudanças que ocorreram frente aos problemas e desafios que encontramos. Criamos a primeira verdadeira antologia online da literatura de Libras dentro da definição de antologias de Di Leo (2004) (e pode ser que seja a primeira de quaisquer línguas de sinais no mundo). A construção esteve sujeita aos "acidentes" que acontecem em qualquer atividade pioneira (RAMOS, 2000) e a partir desses acidentes a proposta foi contando com estratégias para conhecer melhor o novo terreno, evitar que os mesmos acidentes se repitam no futuro e prever outros possíveis problemas antes deles acontecerem. Neste artigo, apresentamos então este processo de constituição da primeira antologia literária em Libras.
\end{abstract}

PALAVRAS-CHAVE: Antologia de Libras. Literatura em Libras. Literatura surda.

\footnotetext{
* Professora e pesquisadora da Universidade Federal de Santa Catarina, no Departamento de Libras e coordenadora do grupode pesquisa Literatura em Línguas de Sinais. E-mail:rachel.suttonspence@ufsc.br.

** Professora e pesquisadora da Universidade Federal de Santa Catarina, no Departamento de Libras e pesquisadora da Antologia Poética em Língua Brasileira de Sinais, Antologia Literatura em Língua Brasileira de Sinais e coordenadora FestivalFolcloreSurdo.E-mail: fernanda.machado@ufsc.br

*** Estudante e pesquisadora da Universidade Federal de Santa Catarina, no Departamento de Libras e integrante do grupo de pesquisa Antologia de Literatura em Língua de Sinais, integrante do grupo Festival de Folclore Surdo. Email: lulumaciiel@gmail.com

**** Professora e pesquisadora da Universidade Federal de Santa Catarina, no Departamento de Libras e pesquisadora doCNPq.E-mail:ronice.quadros@ufsc.br.
} 
RESUMEN: Este artículo presenta la constitución de antologías literarias en Libras. Específicamente, se presentarán los elementos metodológicos y teóricos que guiaron la creación de la Antologia Literaria de Libras publicada en el Portal de Libras como parte integrante de la Documentação de Libras. El objetivo de este artículo es describir los fundamentos teóricos y prácticos en el proceso de creación de una antología de literatura en Libras, que podrá servir de referencia para futuras antologías literarias en lengua de señas. La antología integrante del portal de Libras se compone de 50 ejemplos de obras literarias en Libras, seleccionados de acuerdo con diversos criterios, considerando los usuarios que incluyen profesores, alumnos, artistas e investigadores. Una antología sirve como instrumento para promover la literatura en Libras. Es por medio de las antologías que conocemos las literaturas del mundo, incluso las de las comunidades sordas brasileñas. En este artículo presentamos el origen de tal antología, el proceso de evolución y los cambios que se fueron dando frente a los problemas y desafíos que encontramos. Hemos construido la primera verdadera antología online de la literatura de Libras dentro de la definición de antologías de Di Leo (2004). (y es posible que sea la primera en lengua de señas en el mundo). La construcción estuvo sujeta a los "accidentes" que ocurren en cualquier actividad pionera (RAMOS, 2000) y a partir de esos accidentes la propuesta fue contando con estrategias para conocer mejor el nuevo terreno, evitar que los mismos accidentes se repitan en el futuro y prever otros posibles problemas antes de que estos ocurran. Entonces, en este artículo presentamos ese proceso de constitución de la primera antología literaria en Libras.

PALABRAS CLAVE: Antología de Libras. Literatura en Libras. Literatura sorda.

ABSTRACT: This article considers the creation of literary anthologies in Libras, focusing on the methodological and theoretical elements that guided the making of the Anthology of Libras Literature published in the Libras Portal as part of a larger project for Documentation of Libras. We describe the theoretical and practical details underpinning the process of creating an anthology of Libras literature that may serve as a reference for future literary anthologies in sign languages. The anthology of the Portal de Libras contains 50 examples of literary works in Libras selected according to criteria that we considered important for such users as teachers, students, artists and researchers. An anthology is a resource for promoting Libras literature. It is through anthologies that we come to know the world's literatures, including that of the Brazilian deaf community. In this article, we present the origin of this anthology, the process of evolution and changes that occurred in response to the problems and challenges we encountered. As far as we know, we have created the first online anthology of Libras literature (and it may be the first of any sign languages in the world). Its construction was subject to "the accidents expected on the journey of any pioneering initiatives" (RAMOS, 2000, p. 1) and, learning from these accidents, the proposed anthology developed strategies to better understand the new terrain, to prevent the same accidents from recurring in the future and to foresee other potential problems before they happen. Thus, in this article, we present this process of the making of the first literary anthology in Libras.

KEYWORDS: Anthology of Libras. Literature in Libras. Deaf literature.

\section{INTRODUÇÃO}

A documentação da Libras inclui uma Antologia Literária em Libras com diferentes objetivos que se dividem em duas frentes: (i) a pesquisa e (ii) o acesso às produções literárias em Libras pela comunidade em geral, especialmente, os professores de Libras. Em relação a primeira frente, o objetivo está em estabelecer uma referência literária devidamente organizada em categorias incluindo a identificação dos gêneros literários e suas características. A produção das pesquisas no campo da Literatura produzida em línguas de sinais foi considerada para definir estes elementos que poderão servir como referência para pesquisas literárias da Libras e de outras línguas de sinais, assim como servir de ponto de partida para o aprimoramento das análises literárias de produções em línguas de sinais. O segundo objetivo da documentação da Libras por meio de uma Antologia Literária em Libras é a socialização de produções que são consideradas obras literárias entre os professores que ensinam Literatura em Libras no espaço educacional, assim como para demais interessados. Os professores encontram no Portal de Libras o acesso à documentação da Libras no formato de uma Antologia Literária que pode ser acessada, consultada e compartilhada com seus alunos como parte integrante do ensino com diferentes objetivos pedagógicos.

Por que um artigo sobre a construção de uma antologia da literatura em Libras é importante? Muitas antologias literárias, em nossa experiência, são apresentadas com pouca ou nenhuma explicação sobre o objetivo da antologia ou o raciocínio de sua construção. 
No entanto, a criação da antologia de literatura em Libras foi um processo pioneiro, em que nada pode ser esperado e que exigiu muitas decisões com implicações importantes. Assim, essa discussão serve para a compreensão de antologias, de antologias em Libras e a compreensão da literatura de Libras.

Existe uma questão fundamental: o que é literatura em Libras? Em qualquer contexto histórico ou ambiente social, a resposta será diferente. Uma função das antologias é ajudar-nos a entender por que há tantas respostas. A forma, a origem e a função da literatura em Libras apresentam muitas variáveis. Para saber o que podemos abranger em uma antologia, precisamos saber o que é a determinada antologia na qual incluiremos uma produção. Por outro lado, sabemos o que é apenas depois de coletar e estudar as produções literárias dos surdos. As perguntas "o que faz parte de uma antologia de literatura em Libras?" e "o que é literatura surda?" são dois lados de uma mesma moeda.

Nesse artigo, descrevemos o que coletamos, como escolhemos os exemplos, como avaliamos as obras literárias para dizer que integram a antologia que decidimos compor e por quê. O objetivo foi criar uma coleção de textos em Libras para ser estudada e para ser apreciada. Uma antologia de literatura em Libras valoriza a literatura da comunidade surda brasileira e, com isso, possibilita entender melhor as perspectivas linguísticas, culturais, históricas, políticas e estéticas dos sinalizantes de Libras - veja Cirillo (2004) sobre a importância similar de uma antologia de literatura no Caribe. As antologias visam incentivar os usuários a conhecerem e estudarem a literatura apresentada dentro delas e a buscar mais exemplos análogos ou diferentes motivados por elas (LEITCH, 2004).

Embora saibamos que existem diversos tipos de antologia, um dos mais comuns é a antologia de ensino. O aluno surdo na escola como primeira língua e o aluno ouvinte aprendendo Libras como segunda língua devem estudar literatura em línguas de sinais (PARAN 2008; SUTTON-SPENCE, 2020). Nos últimos anos, a literatura em Libras se tornou um tema de estudo de nível universitário, surgindo a necessidade de acesso a alguns exemplos para o ensino. Todos esses estudantes precisam de recursos para os estudos.

Em qualquer nível de ensino, devemos perguntar: o que ensinamos e por quê? Uma antologia de literatura surda em Libras deve incluir produções que são parte do "cânone". Um cânone literário é um conceito abstrato, que não existe fisicamente, mas é sim a ideia do conjunto de todos as produções literárias que os líderes e os membros de uma comunidade reconhecem como "principal". Uma antologia é uma coleção física, baseada no cânone. Por outro lado, a antologia cria o cânone porque as produções numa antologia ocupam um status reconhecido (DI LEO, 2004).

Antologias têm funções centrípetas e centrífugas (DOWNING, 2004). De forma centrípeta, elas tentam juntar exemplos díspares para criar definições em relação ao material selecionado na antologia (por exemplo "o que é literatura de libras como a vemos hoje" e "como é a literatura em Libras apresentada nesta antologia"). Esse processo de padronização cria cânones, estabelecendo normas literárias, ajudando a identificar a importância das normas e a perpetuá-las, principalmente por meio do ensino. Por outro lado, de forma centrífuga, uma antologia deve refletir a realidade, com toda a sua incerteza e desafios às definições, enfatizando a pluralidade, a diversidade e o desenvolvimento dessa forma de arte linguística e sociocultural. Assim, eles podem desafiar essas normas, mostrando suas limitações. As antologias trazem novo material para o cânone, rompendo as tradições, o que encoraja iniciativa, criatividade e o não conformismo enquanto pensam nos padrões (no sentido de estar "fora da caixa").

As antologias on-line são selecionadas de uma ampla variedade de outros materiais disponíveis. A publicação anárquica de material literário em Libras na internet não possui regras que restrinjam sua publicação e nenhuma organização por hierarquia ou autoridade. A seleção de material com base no que a maioria da comunidade considera "bom" reflete as normas da comunidade e tenta apresentar o material de maneira gerenciável. A questão de quem afirma representar a comunidade na aplicação das normas torna a posição dos organizadores sempre discutível e desafiadora.

As antologias fornecem materiais para a crítica literária, a criação artística e o ensino da literatura. Precisamos pensar na leitura das produções (perguntando o quê, por que e como lemos/assistimos a literatura) e nas criações (perguntando o quê, por que e como a produzimos). Do ponto de vista pedagógico, isso se torna facilmente uma questão prescritiva sobre o quê, por que e como devemos 
ler/assistir e produzir. Downing (2004, p. 343) observa que as antologias são a base dos livros didáticos ou mesmo servem como livros didáticos em muitos casos. Ele destaca a inegável importância dos livros didáticos sobre literatura inglesa em "[...] estabelecer o cânone ou reforçar tradições canônicas, instilar atitudes em relação à literatura e à linguagem e determinar como a literatura e a composição serão ensinadas". Deve ser o mesmo para a literatura em Libras. No entanto, até que uma pessoa conheça as regras atuais da literatura, ela não poderá quebrá-las.

Assim, neste trabalho pioneiro de criar uma antologia, precisamos saber quais são essas produções canônicas. Para conseguir isso, precisamos entender as normas literárias da comunidade surda. Normas são os valores aprovados de uma comunidade e as normas literária da comunidade surda brasileira regulam o que os surdos avaliam como adequado na sua literatura, a linguagem, o estilo e a função. As normas não são sempre articuladas explicitamente pelos membros da comunidade, mas são subentendidas (CAMPOS, 2017). Normas não são prescritivas, mas sim descritivas, e evoluem por anos, sendo estabelecidas, mantidas e promulgadas muitas vezes pelo ensino, e por isso pelas antologias de ensino.

\section{LITERATURA EM LIBRAS}

Não é a nossa intenção neste artigo definir a literatura em Libras, embora essa questão gere um dos principais desafios na criação de uma antologia: como podemos criar uma antologia de literatura em Libras sem saber o que é? Por enquanto, podemos dizer que a literatura se centra na linguagem estética visual e cria uma experiência emocional afetiva para o seu público, em vez de apenas afirmar algo ou dar uma informação. A literatura em Libras se centra na forma estética da Libras que tem características fora do comum, trata do conteúdo com perspectiva não cotidiana e se apresenta de uma maneira que seria diferente da vida comum. Seguindo Sutton-Spence e Kaneko (2016, p. 24), dizemos que a literatura é qualquer "[...] corpo de produções baseado na linguagem que é considerado socialmente, historicamente, religiosamente, culturalmente ou linguisticamente importante para a comunidade." É uma oportunidade de brincar com Libras, de explorar as possibilidades e os limites e dar prazer aos leitores ou "visualeitores" seguindo a sugestão de Mourão (2016). É a expressão da perspectiva visual do mundo por uma pessoa surda através da língua de sinais.

Um principal desafio para uma antologia de literatura em Libras é compreender as diversas formas dessa arte linguística para selecionar o que possa ser valorizado. Há perspectivas diferentes sobre conceitos parecidos, como literatura surda, literatura em Libras e literatura sinalizada.

A literatura surda é definida pelo conceito da experiência dos surdos. Pode ser literatura feita por surdos, destinada aos surdos ou sobre os surdos. Segundo Mourão $(2011,2016)$, as produções de literatura surda podem ser narrativas originais de autores específicos, adaptações de narrativas tradicionais que incluem algo da vida dos surdos, traduções de narrativas tradicionais ou outras narrativas de línguas escritas. Com o mesmo foco nos produtores surdos e no público surdo, Resende (2019) destaca tipos de teatro como teatro dos surdos (produzidos por e para pessoas surdas), teatro com surdos (em que surdos e ouvintes produzem juntos), teatro para surdos (em que uma peça criada pelos ouvintes seja traduzida, adaptada e apresentada pelos surdos), teatro bilíngue (em que uma peça está apresentada simultaneamente em Libras e Português por um elenco surdo e ouvinte). Na antologia de literatura em Libras, todas as produções são feitas por artistas surdos e destinadas primeiramente a um público surdo, mas a origem não é sempre da comunidade surda, havendo exemplos de traduções, recontações e adaptações de literatura (e folclore e filmes) da comunidade maior dos ouvintes. Muitas das produções - mas não todas - falam da experiência de pessoas surdas.

A literatura em Libras é definida pelo fato de ser produzida numa língua articulada no primeiro plano em sinais e não numa língua falada. Neste caso, dentro da Literatura Surda, a definição prioriza a língua. Literatura Surda Brasileira pode ser escrita na língua portuguesa, se for produzida por uma pessoa surda, sobre um assunto relacionado à experiência surda ou destinada aos surdos, mas a literatura em Libras é definida pelo uso estético de sinais e não importa a origem. No caso da nossa antologia, todas as produções são em Libras. 
Literatura em Libras sinalizada significa que a modalidade da literatura apresentada é articulada pelo corpo (de uma forma "ao vivo", análogo ao sentido de "oral", declamada) e não escrita. Há diversos exemplos de literatura em Libras escrita, principalmente, literatura infantil (MARQUEZI, 2018) e poesias (BARROS; VIEIRA, 2020). No entanto, para nossa antologia, selecionamos apenas produções em Libras sinalizada.

Há estudos de literatura surda que já foram feitos com base em diversos fundamentos teóricos. Os estudos culturais (KARNOPP, 2013; KARNOPP; KLEIN; LUNARDI-LAZZARIN, 2011), crítica literária (PEIXOTO, 2016), linguística (MACHADO, 2013; KLAMT, 2018), tradução (BARROS, 2015) e cinema (PIMENTA, 2012). Pesquisas existem sobre poesia (KARNOPP; BOSSE, 2018; KLAMT 2014a, 2014b), teatro (REZENDE, 2019), histórias (CASTRO, 2012; VIEIRA, 2016) e piadas (KARNOPP; SILVEIRA, 2014) em Libras. Outras pesquisas mostram a importância social (MOURÃO, 2016) e educacional (BOSSE, 2019) de literatura surda e em Libras. Nossa antologia não adota uma única perspectiva teórica. A formação linguística das organizadoras impacta no sentido de uma abordagem que tem mais foco na linguagem poética e estética da Libras e reflete o uso da "leitura detalhada" (em inglês, Close Reading) com foco principal no texto, na linguagem do texto e nos efeitos do uso dessa linguagem. No entanto, também referimos a outras perspectivas teóricas que podem contribuir para melhor compreensão da literatura em Libras.

\section{OS ELEMENTOS DA ANTOLOGIA}

É inerente à ideia de uma antologia que ela deva ser organizada de alguma maneira, seja pela cronologia, autor, título, gênero, estilo, assunto, público-alvo pretendido ou alguma outra característica que a categorize. Uma antologia on-line é menos dependente de uma única ordem de apresentação como apresentada em uma versão impressa, porque o usuário pode escolher o método de categorização que quiser seguir. No entanto, é necessário anotar essas características para permitir que os usuários possam pesquisar o conteúdo. Nada disso é ateórico. Por exemplo, "gênero" é um conceito problemático, com implicações excludentes de que se algo pertence a um gênero, não pertence a outro. Poucos usuários de uma antologia estarão cientes das justificativas dos organizadores para escolher um método de categorização em detrimento de outro, mas as decisões são fundamentais para a estruturação da antologia e do material e dos valores que são determinados para as escolhas dessas categorias que são inevitáveis.

Após muita discussão, seguimos três categorias na antologia, a partir de gêneros principais baseadas na forma das produções e nas origens (SUTTON-SPENCE; KANEKO, 2016; BAHAN, 2006): Poema, Conto origem não surda e Conto origem surda. Destacamos que todos os poemas na antologia têm origem surda, e não há traduções de poemas do português. Cada gênero foi subdivido em diversos subgêneros, baseado nas pesquisas publicadas sobre literatura surda (por exemplo: ROSE, 2006; BAHAN, 2006; MACHADO, 2017) e nas próprias experiências dos organizadores:

Poemas: Delimitado; Dramático, Dueto, Homenagem, Lírico, Perspectiva, Música surda, Feminista, Haiku

Conto Origem não surda: Filme, Folclore brasileiro, Folclore mundial

Conto Origem surda: Ficção original na tradição surda, História infantil, NEP (Narrativa de Experiência Pessoal), Piada tradicional surda, Teatro tradicional surdo.

Dentro destes subgêneros estão marcadas produções de diversos estilos. Seguindo as divisões de Aristóteles de literatura lírica, dramática e épica, o estilo ponto de vista, pode ser o "Eu”, a Personagem (por Incorporação), o Narrador ou "misto". Relacionada a essa divisão, a antologia marcou o estilo linguístico, sendo composto, principalmente, por vocabulário/sinais estabelecidos, classificadores, incorporação ou misturado. O último estilo destacado foi o metafórico, em que anotamos se a produção seja principalmente literal ou metafórica.

Sabendo que se pode categorizar literatura pelo público-alvo, anotamos o público apropriado: adulto, adolescente, jovem e infantil.

Além da definição da estrutura da antologia, a criação de conteúdo e a escrita das notas introdutórias foram as duas tarefas principais. As notas introdutórias preparam o leitor/visualeitor para que eles estejam prestes a ver a obra literária selecionada e motivados a explorá-la mais (por exemplo, procurar outras obras do autor, outros exemplos de um dado estilo ou gênero, ou algo 
destinado a um público semelhante). Essas notas introdutórias numa antologia de ensino são geralmente pequenos ensaios que fornecem uma introdução geral às épocas da literatura, informações sobre cada autor e anotações de cada texto (LEITCH, 2004). As antologias contam com pontos de referência chamados The Norton Anthologies que fazem parte de uma série de antologias de literatura para ensino, sendo coleções de obras canônicas publicadas com notas introdutórias. Usamos uma adaptação dos Protocolos para Notas Introdutórias de Antologia sugeridos pelos organizadores do Norton apresentados por Leitch (2004), o que inclui:

1. Nome e datas do autor e uma citação do (ou sobre o) autor.

2. Informações biográficas chaves sobre o autor.

3. Referência a outras publicações do autor.

4. Breves descrições de quaisquer fontes ou versões anteriores da obra selecionada.

5. Qualquer informação social ou histórica relevante útil para entender o contexto da obra selecionada.

6. Resumo das principais ideias da obra selecionada.

7. A importância ou o uso atual da obra selecionada.

8. Importantes semelhanças e diferenças entre esta obra selecionada e outras obras na antologia.

9. Declaração de quaisquer questões sobre a seleção da obra.

10. Como a obra foi recebida inicialmente.

11. Lugar da obra selecionada em contextos históricos, literários ou sociais.

12. Explicação dos principais termos e conceitos.

13. Quaisquer questões problemáticas com a obra selecionada.

14. Material adicional, por exemplo fontes secundárias sobre o autor ou a obra e bibliografia de outras produções do autor.

A antologia é em Libras, mas as notas introdutórias precisam estar em português, para permitir uma busca rápida no sistema online. Leitch (2004) observa que as notas introdutórias nas Norton Anthologies têm em média 2.000 palavras por item. A prioridade da antologia de literatura em Libras era montar o conteúdo (que incluía a criação desse conteúdo) com foco na obra literária e não no comentário. Nossa solução para o problema foi dividir o trabalho das notas introdutórias em duas partes. Primeiramente, para a antologia on-line, criamos fichas curtas, com os principais elementos, conforme segue: a) informações biográficas básicas sobre o autor; b) informações sobre o contexto da produção da obra literária (por exemplo, onde, quando e por que foi realizado); c) um resumo da obra; d) observações que tratam de alguns dos pontos entre 7-14 acima; e) uma captura de tela da produção da obra que mostre o autor produzindo um sinal-chave do trabalho (paralelo ao protocolo para fornecer uma citação). Em segundo lugar, as notas introdutórias estendidas se transformaram em um livro sobre literatura de Libras (SUTTON-SPENCE, no prelo). Este livro tem como objetivo atender ao aspecto didático da antologia, permitindo uma exploração mais detalhada de tópicos como os contextos históricos, literários ou sociais das obras selecionadas e explicação de termos e conceitos-chave, além da apresentação de pesquisas adicionais sobre literatura em Libras.

\section{ANTOLOGIA DA LITERATURA EM LÍNGUA DE SINAIS NO MUNDO}

A antologia está presente em diferentes espaços no mundo e é organizada de acordo com suas especificidades. As antologias de literatura surda escrita são compostas por trabalhos elaborados por diversos autores.

Nos Estados Unidos, o trabalho Antologia: Formas surdas II, (em inglês The Deaf Way II) de Stremlau (2000) apresenta escritos criativos contemporâneos de pessoas surdas. Além disso, inclui o trabalho com histórias reescritas e reeditadas, com o título Mudança poderosa: uma antologia das escritas de surdos americanos, 1816-1864, (em inglês A Mighty Change: An Anthology of Deaf American Writing") de Krentz (2000) e a antologia temática Olhos de Desejo: uma coleção por Surdos Gays e Lésbicas, (em inglês Eyes of desire: a Deaf Gay \& Lesbian Reader) de Luczak (1993).

O livro Antologia: Formas surdas II" foi produzido partir da 2a Conferência e Festival Formas Surdas, que aconteceu na Gallaudet University, em Washington, DC, em julho de 2002. Este evento contou com mais de 9.000 pessoas presentes, entre pesquisadores, 
artistas, intérpretes, estudantes e interessados, instaurando um espaço de interação social que provocou a organização da antologia. Esta antologia é uma coleção que reuniu 16 autores surdos internacionais, com autores surdos e deficientes auditivos. Estão compreendidos nesta antologia trabalhos envolvendo poesia, teatro, conto e uma peça teatral.

O Livro Uma Mudança Poderosa por Krentz (2000) contém escritos originais de pessoas surdas da primeira metade do século XIX, quando teve início a educação de surdos nos Estados Unidos. Iniciou com a obra de um surdo francês que foi para os Estados Unidos em 1786 e criou a primeira escola de surdos nos Estados Unidos. Outros escritores surdos que fazem parte da obra, incluindo um poeta surdo, em especial, produziram o verso melífero, publicado nesta coleção.

A antologia temática Olhos de desejo, uma coleção por surdos gays e lésbicas (em inglês Eyes of Desire, A Deaf Gay \& Lesbian Reader), de Luczak (1993) apresenta discussões envolvendo a vida de lésbicas e gays surdos, relatando como descobriram suas identidades, suas lutas, sua comunicação com o mundo e as questões culturais envolvendo gays e lésbicas surdos.

Na Grã-Bretanha, o trabalho Linguagem para os olhos: antologia de escrita e publicação de surdos (em inglês Language for the Eye: Anthology of Deaf Writing and Publishing) é uma publicação contendo autores surdos, com a organização de George Montgomery (1996), uma coleção que reúne autores e obras literárias escritas.

A antologia literária, especificamente tratando das produções surdas, como A musa silenciosa: uma antologia de prosa e poesia pelos surdos (em inglês The Silent Muse: an Anthology of Prose and Poetry by the Deaf) de 1960, edição Panara, Denis e McFarlane, reúne prosa e poesia de estudantes surdos escritores, tendo sido publicado pela Gallaudet University Press. A obra compreende temáticas sobre angústias e fragilidade emocional relacionada à história do sujeito surdo, bem como histórias relacionadas às "mulheres más".

A obra Poesia Surda Americana, (em inglês Deaf American Poetry) de John Lee Clark (2009), reúne uma coletânea de textos importantíssimos escritos em inglês por surdos americanos. Essa coletânea reúne 95 poemas, redigidos por 35 poetas surdos americanos, que relatam suas vidas através de versos sinalizados. Este trabalho é um marco na história de poetas surdos americanos e retratam o contexto em que se inserem os poetas, suas experiências e histórias de vida.

As antologias bilíngues são uma produção de poetas surdos e utiliza os registros nos formatos escrito e sinalizado. A poetisa surda inglesa Dorothy Miles produziu duas antologias que foram publicadas separadamente. A primeira, de sua autoria, intitulada, Gestos de Dorothy Miles (1976), é uma coleção bilíngue em ASL e inglês. A segunda, Memória Brilhante (1998), em inglês Bright Memory) foi organizada por Don Read depois do falecimento inesperado dela e foi publicado em inglês.

Destacamos também algumas organizações de poemas que resultaram em coleções. Na língua de sinais britânica (BSL), BSL Poetry, de Paul Scott (2006), e Made by Hand, de Richard Carter (2013). Nessas duas coleções, há um pequeno resumo sobre os poemas. Nos Estados Unidos da América , existe uma produção em DVD que contempla três artistas e seus poemas: Clayton Valli, Patrick Graybill e Debbie Rennie. Sendo que esta última apresenta comentários sobre seus poemas. Como pode ser observado, é possível, por meio de uma organização, reunir produções de mais de um artista em uma antologia. Além de poeta, Clayton Valli (1995) organizou a ASL Poetry, convidando poetas de diferentes idades para compor essa antologia. Nesta antologia, há comentários sobre os poemas.

Retomando o contexto europeu, temos o poeta holandês Wim Emmerik com suas produções intituladas de Poetry in Sign Language, de 1995, e de Motioning, de 2005, coproduzida com Giselle Meyer em língua de sinais holandesa (NGT). Além dessas, Rosaria e Giuseppe Giuranna, em 2000, produziram sete poemas em língua de sinais italiana (LIS).

Já nos EUA, o documentário The Heart of the Hydrogen Jukebox apresenta as histórias e produções de poetas da ASL do século XX, produzido por Nathan Lerner e Feigel. Nessa produção de 2009, são reunidos poetas surdos estadunidenses e suas experiências no National Technical Institute of the Deaf em Rochester, New York. Podemos considerar essa produção como uma antologia que, de algum modo, abarca poemas e comentários que auxiliam a sua compreensão. Essa produção é um marco histórico salvaguardado. 
Com a tecnologia atual, é possível disponibilizar uma antologia on-line por meio de vídeos em plataformas. Um exemplo disso é a European Community Heritage Online, organizada por Onno Crasborn no período entre 2003 e 2005. Para compô-la, foram convidados artistas surdos holandeses, suecos e ingleses com suas produções, dentre elas, poemas, narrativas e prosas. Deste modo, ela foi disponibilizada de forma on-line como uma antologia poética em língua de sinais. Seu corpus contempla a literatura em seus gêneros diversos como narrativas em prosa. Esses metadados, analisados e detalhados, compõem comentários das poesias.

A primeira antologia criada de poesia em BSL foi organizada por uma equipe na University of Bristol, na Inglaterra, e recebeu financiamento para ser produzida. A equipe responsável pela organização realizou pesquisas, reuniu e disponibilizou 120 poemas em BSL de maneira on-line e com tradução para o inglês. A antologia está disponível, com livre acesso, na plataforma YouTube. A criação desta antologia influenciou a criação da antologia da literatura em Libras

\section{ANTOLOGIA DE LITERATURA SURDA BRASILEIRA: EM PORTUGUÊS E EM LIBRAS}

Nesta seção, vamos apresentar publicações literárias pré-existentes à antologia literária que estamos compartilhando por meio do Portal de Libras (LIBRAS, 2020). Essas produções podem ser escritas e/ou produzidas em Libras.

Falando de Literatura Surda Brasileira escrita, no Brasil, a antologia literária O som das palavras, publicada em 2003, sem autor ou organizador, apresenta obras escritas produzidas por surdos em português.

Em relação às antologias bilíngues brasileiras, produzidas por diversos autores, publicadas em língua portuguesa e Libras, podemos citar o trabalho de Ronise Oliveira, intitulado Os meus sentimentos em folhas, de 2005, e a publicação da poeta Emiliana Rosa, intitulada Borboletas Poéticas. Ambos os trabalhos publicados em língua portuguesa. Essas coleções reúnem textos literários tanto de surdos quanto acerca da Libras e destacam informações históricas de temas variados.

Diversos materiais estão disponíveis também em redes sociais, como YouTube, Facebook, Instagram e blogs, que são de responsabilidade e organizados pelos próprios autores. As antologias, por sua vez, são organizadas de acordo com critérios específicos e colaboram no sentido de detalhar e explorar determinada temática.

No Brasil, em Libras, temos a Literatura em LSB, organizada e comentada por Nelson Pimenta (1999), a qual foi a primeira, com poemas, história de ABC e outros contos, inclusive uma fábula de origem surda e contações de clássicos infantis. Há também Piadas em Libras (2009) uma coleção de piadas, de Sandro Pereira em DVD que integram a categoria humor em Libras.

O site Cultura Surda (2020), de responsabilidade de Hugo Heiji, de São Paulo, oferece acesso a um amplo material produzido no Brasil e em outros países. O site Librando (2020), da UFSC, com a organização de Michelle Schlemper disponibiliza diversos materiais de literatura nacional e internacional.

O Instituto Nacional de Educação de Surdos - INES, instituição educativa de surdos apresenta também material literário produzido por professores e estudantes. O Diário de Bel (2020), Bel e Tobias continuam explorando o folclore brasileiro e mundial. Contação de História (2020) integra uma série que visa tornar acessível a literatura infantil e juvenil para a comunidade surda de todas as idades. Baú do Tito (2020) usa imaginação e mergulha no Baú do Tito. Piadas em Libras, com personagens surdos, como Comédia da Vida Surda (2020) que tem como objetivo fazer rir e mostrar os desafios do cotidiano de pessoas surdas. A Louca Olimpíada (2020), uma comédia que explora os gestos e a língua de sinais. O material do INES está disponível no site da TV INES. Também há publicações literárias disponíveis no Centro de Educação para Surdos (CES) - Rio Branco (2020), São Paulo. O CES apresenta Contações de Histórias, Piadas em Libras, Lendas e Comemorações em Libras.

Os materiais disponibilizados por meio de projetos das universidades também compreendem uma fonte de produções literárias. Entre eles, há o projeto do curso de poesia de um grupo fechado na plataforma Facebook com vídeos de poemas em Libras está 
disponível em Repositório da UFSC, organizado por Fernanda Machado e Rachel Sutton Spence e oferece acesso a produções literárias de estudantes surdos. É possível acessar as informações de autoria, dentre outras informações.

Outro projeto é o site de Festival de Folclore Surdo que é outro espaço no qual são socializadas produções literárias em Libras. Este site é coordenado por Fernanda Machado e Rachel Sutton-Spence e trata de materiais registrados previamente e materiais novos produzidos, incluindo contos, humores, poesias, teatros em Libras, narrativas e entrevistas com artistas no evento Festival de Folclore Surdo e disponibilizadas em Repositório da UFSC (edições 2014, 2016, 2018). Incluímos entrevistas com artistas que participaram no evento Workshop de Literatura Surda, do Festival de Folclore Surdo 2018. Os artistas falam da sua experiência e visão de literatura surda. Os direitos autorais ficam com os artistas. As entrevistas são reproduzidas aqui com a permissão dos artistas.

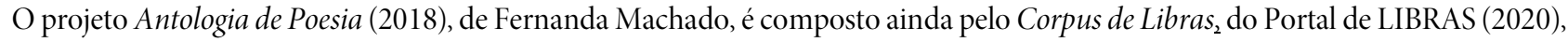
organizado por Ronice Quadros, ambas da UFSC. Este portal oferece buscas por tags, com informações detalhadas por região. O projeto de extensão da UFSCar, Atenção Bilíngue Virtual (2020) para crianças surdas em meio à pandemia do coronavírus.

O Mãos Literárias (2020) é projeto realizado dentro da Faculdade de Letras da UFMG e produz vídeos de contação de histórias em Libras. O site de A Arte de Sinalizar (2020) trata de material produzido a partir de batalhas poéticas, apresentações em vários gêneros literários: narrativas, humores e poesias, disponibilizadas em repositório artístico, pela UFRGS, é coordenado por Claudio Mourão. Mãos Aventureiras: canal de histórias infantis em Libras, de Carolina Hessel (2020), da UFRGS. Ainda há o projeto do Cordel em Libras por Klicia Araujo (2020), da UFPR, tradução da literatura nordestina.

Acerca das antologias em Língua de Sinais especificamente, temos a Antologia da Poética em Língua de Sinais Brasileira, de Fernanda Machado (2018), da Universidade Federal de Santa Catarina. No entanto, não existia no Brasil nenhuma antologia literária da Libras, de produções em Libras selecionadas e acompanhadas por perfis dos artistas, análises de elementos constituintes das produções, contextualização de cada obra e estruturas das produções. Por isso, foi proposta a antologia que apresentamos aqui organizada por Rachel Sutton Spence e Fernanda Machado, também da Universidade Federal de Santa Catarina.

\section{METODOLOGIA}

A partir de estudos sobre antologias de ensino e um levantamento de coleções de literatura em línguas de sinais internacionais, começamos com uma proposta para a antologia, que seria dividida em quatro categorias. A primeira categoria conteria vinte poemas, a segunda categoria dez contos, a terceira categoria dez fábulas e a quarta dez clássicos da literatura infantil. Prosseguimos dessa forma, com essas categorias definidas e começamos o trabalho de pesquisa e organização, fazendo as coletas necessárias para cada uma dessas categorias literárias. Isso exigiu uma exploração e um levantamento em relação ao que já havia sido produzido como literatura em língua de sinais no país. Eram várias produções e com inúmeros tipos de literatura que abrangiam todas as regiões do Brasil e que estavam armazenadas em sites da internet.

Nessas categorias, buscamos materiais em diversas fontes. Alguns eram de materiais já existentes, tais como: o repositório de produções de festivais de folclore surdo; vídeos que encontramos nas redes sociais, como Youtube, Facebook e Instagram. Em outros, nós criamos os espaços para a produção dos materiais novos (MAZZA, 2004). Um curso de poesia, realizado na modalidade a distância, ofertado no Facebook pelas professoras que também organizaram a antologia, forneceu muitos exemplos. O workshop de literatura surda em 2018 foi montado e sediado em Florianópolis com vários palestrantes nacionais e internacionais para quem pedimos a apresentação de uma narrativa para incluir na antologia.

A coleta de narrativas de experiência pessoal (NEP) foi feita por alunos da graduação do curso de Letras Libras da modalidade a distância de três polos abertos no Amazonas, Ceará e Minas Gerais. Os alunos conseguiram encontrar e filmar artistas idosos nas comunidades surdas das suas próprias cidades, os quais eram difíceis de serem encontrados pela equipe em Santa Catarina. 
Quando percebemos através das buscas que faltava literatura surda infantil original de natureza pedagógica, organizamos e criamos um projeto para criar literatura para alunos surdos inseridos na educação infantil e no ensino fundamental. O objetivo também era avaliar e testar esses materiais nas escolas do Brasil. Este grupo contava com professores surdos da UFSC e alunas surdas de graduação dos cursos de Letras Libras, nas modalidades presencial e a distância. Mais duas professoras ouvintes com especialidade na literatura infantil e nos estudos literários de Libras acompanhavam os trabalhos, promovendo interações e orientações. Uma aluna de graduação criou imagens adequadas para a faixa etária alvo e os vídeos foram gravados e editados por um cineasta profissional. Todas as literaturas infantis possuíam três elementos. O primeiro deveria ser um jogo de incorporação de animais ou objetos inanimados, o segundo seria um jogo com configuração de mãos para servir de inspiração para se inventar e criar uma poesia a ser contada (como números de zero a dez ou uma única configuração de mão) e o terceiro deveria ser de humor, para criar um conto lúdico e incongruente, com muito exagero (BERGSON, 1983).

Em relação aos critérios para a escolha desses materiais, tentou-se manter equilíbrio entre as forças centrípetas e centrífugas da antologia incluindo: materiais canônicos e materiais de forma mais experimental; qualidade de gravação sendo adequado para incluir; a clareza de produção dos sinais; o tema; a estrutura da obra; a presença destacada de um de uma lista de elementos estéticos, como incorporação, ritmo e simetria; e a extensão, com a maioria sendo de 1 até 4 minutos. Selecionamos produções de artistas de diversos perfis demográficos e de diversos gêneros. O último critério era que a produção deveria ser memorável. Com apenas 50 obras para escolher, tínhamos que descartar muitos bons exemplos, considerando o tamanho da antologia literária proposta. A antologia final acabou sendo estendida e passou a se compor de 52 obras literárias.

Realizamos entrevistas com as pessoas das obras que nós havíamos catalogado, utilizando dois formatos: presencial ou então virtual, através de e-mail, WhatsApp e conversa por videochamada. Foi elaborado um perfil para cada artista e ele foi organizado em planilhas no Excel, contendo vários elementos, como o nome e sinal do ator, gênero $(\mathrm{h} / \mathrm{m})$, raça, idade, ano de nascimento, idade de aquisição de Libras, origem regional, onde aprendeu Libras, onde se formou como ator ou poeta e se atuou como professor.

Foram criadas fichas para cada obra literária selecionada, com informações sobre o perfil de cada artista. Incluímos também anotações sobre cada obra: gênero literário, subgênero literário, título, o local onde foi filmada a sua produção, narrativa detalhada sobre a sua poesia e o porquê da sua criação, o ano de registro da filmagem, a fonte onde a encontramos e o tempo de duração da filmagem. Todo esse material foi baixado e armazenado no repositório da UFSC e o seu respectivo link inserido na sua ficha para que as pessoas pudessem facilmente acessar e assistir ao seu vídeo. Elaboramos uma planilha detalhada contendo vários elementos linguísticos como efeitos estéticos, configuração de mãos, as direções do olhar, o espaço token e sub-rogado, simetria e antropomorfismo. Outra tabela focava nos temas, como perspectiva dos surdos, relação da comunidade com o mundo ouvinte, comunicação, linguagem e valores, preconceito social e ignorância, mundos sensoriais (BAHAN, 2006). Anotamos os objetivos, como aprimorar as habilidades de sinalização; aprimorar o ensino de L2; ensinar valores culturais, apresentar fortes imagens visuais, criar ligação com o público (RYAN, 1993).

Com tudo isso já concluído, nós enviamos para cada artista uma autorização cedendo uso de imagem a ser assinada por todos e em seguida recolhemos e guardamos tais termos por segurança. Concluído esta etapa, temos a coleção para ser postada no Portal Libras, criado pela UFSC em parceria com o IFSC Bilíngue (LIBRAS, 2020, na aba Antologia Literária em Libras). Todo esse material será organizado e divulgado para que os usuários possam buscar por estes artistas. O público-alvo é diverso, incluindo professores, alunos surdos que tenham a Libras como L1 ou L2 ou pais e mães que tenham filhos surdos e que possam buscar por estes materiais. A proposta é mostrar a todos os interessados essa literatura de forma divertida e prazerosa. Além disso, pesquisadores podem acessar e usar as obras e suas descrições para outras análises. Finalmente, membros das comunidades surdas e quaisquer pessoas que possam ter interesse, podem também ter esse acesso. 
ANTOLOGIA DA LITERATURA EM LIBRAS

Título do poema: Tinder

Título em inglês: Tinder

Gênero literário: Poema

Subgênero literário: Perspectiva

Nome do artista: Anna Luiza Maciel

Perfil do artista:

- Gênero: feminino

- Raça: parda

- Faixa etária de idade: 20 a 29 anos

- Idade de aquisição da Libras: 18 anos

- Origem regional: São Paulo

Data de apresentação: 2018

Local de apresentação: Associação de Surdos da Grande Florianópolis

Comprimento (vídeo): 0:44

Estilo ponto de vista:

"Eu" ( ) Narrador ( ) Incorporação (X) Misto ( )

Estilo metafórico:

Literal (X) Metafórica ( )

Estilo linguistico:

Vocabulário sinais ( ) Classificadores () Incorporação (X) Misturado ( )

Público apropriado: Jovens/Adultos

Link: httros://repositorio,ufsc.,br/handle/123456789/191088

Resumo dos recursos

\begin{tabular}{|l|l|l|l|l|l|l|}
\hline Antropomorfismo & & & & & & \\
\hline Morfismo & & & & & & \\
\hline Direção olhar & & & & & & \\
\hline Configuração de mão & & & & & & \\
\hline Neologismo & & & & & & \\
\hline Simetria & & & & & & \\
\hline Uso de espaço & & & & & & \\
\hline Ritmo & & & & & & \\
\end{tabular}

Figura 1a: Exemplo da ficha contendo a planilha descritiva de cada obra 
Objetivo e conteúdo

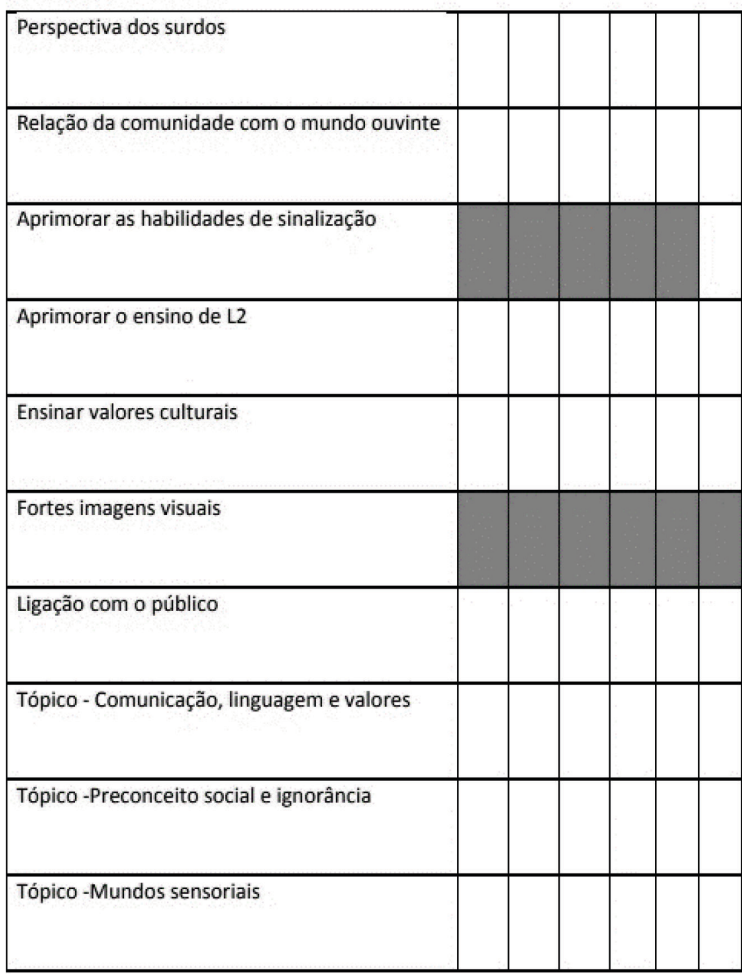

Figura 1b: Exemplo da ficha contendo a planilha descritiva de cada obra (continuação)

\begin{abstract}
Notas: Este material foi utilizado em uma atividade sobre $\mathrm{o}$ uso de perspectivas diferentes na aula de poesia online através do Facebook ministrada pelas professoras Fernanda Machado e Rachel Sutton-Spence na UFSC.

Resumo: Uma mulher usa o celular e o celular está sendo usado. A mulher procura amor no aplicativo celular para relacionamento chamado "Tinder" no final do poema, ela tira um print de uma imagem que gostou;

Tema: Celular, tecnologia, encontro de amor;
\end{abstract}

Observação: Um bom exemplo de antropomorfismo de objeto inanimado. Não usa sinais de vocabulário.

Abre sem título. A poetisa avisou que podemos usar o título "Tinder".

Zoom e plano - Dois papéis de incorporação - a mulher e o celular, para mostrar as experiência do usuário e do objeto. Orientação da mão apresenta o ponto de vista dos personagens para que seja possivel sua identificação. Utilizam-se classificadores para mostrar as páginas no celular.

Mão quando é celular mostra tamanho da tela, ou páginas passando na tela, ou a mão do usuário. 0 último sinal é um desafio ao público, no entanto quem presta atenção (e conhece essa função no celular) percebe que a mulher faz "print" da tela.

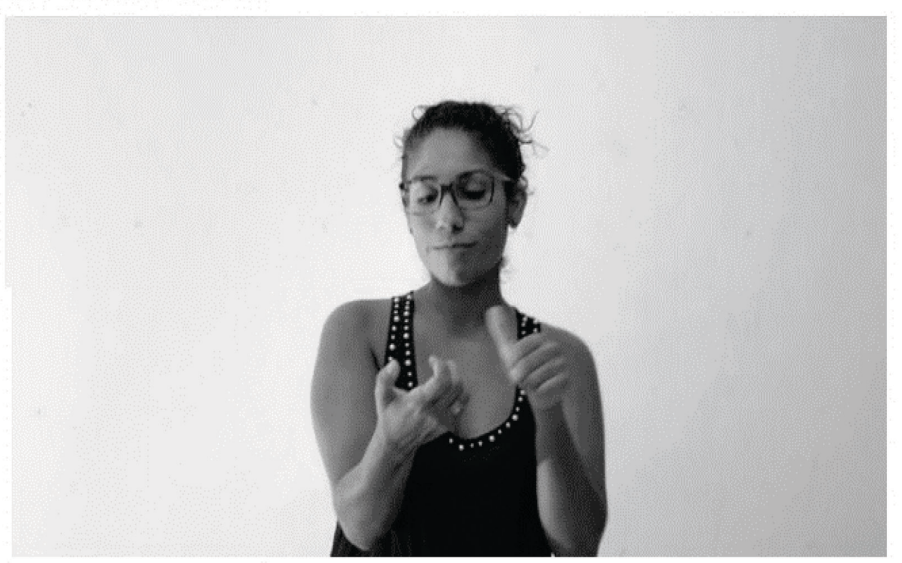

Figura 1c: Exemplo da ficha contendo a planilha descritiva de cada obra (continuação)

Fonte: elaboração das autoras (2020) 
A seguir, apresentamos um mapeamento da representação das obras literárias selecionadas quanto ao gênero, a etnia, a origem regional, formação, atuação como professor, gêneros e subgêneros das produções.

Na antologia, tivemos uma representação de 59\% de produções de mulheres e $41 \%$ de produções de homens (gráfico 1). As mulheres compreendem a maioria nas áreas de poesia e nos contos infantis. Pensando no desequilíbrio histórico a favor dos artistas homens nas coleções de literatura surda (SUTTON SPENCE, 2019), um pequeno desequilíbrio a favor das mulheres ajuda a atingir uma melhor representação do gênero.

\section{Identidade de gênero}

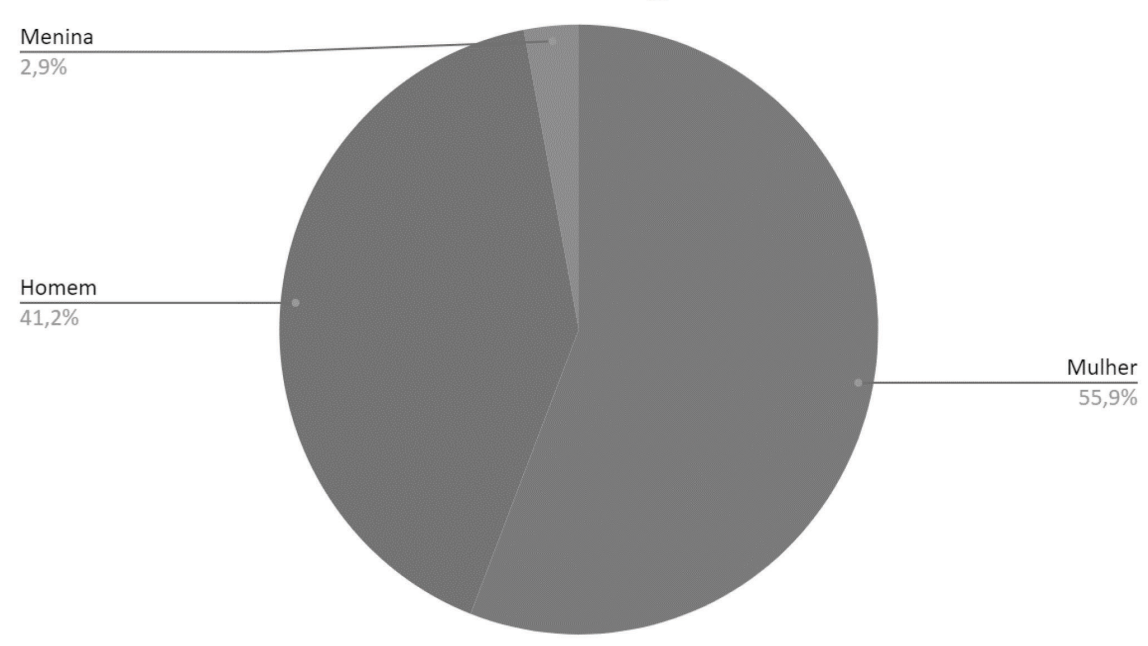

Gráfico 1: Gênero dos artistas

Fonte: elaboração das autoras (2020)

A raça ou etnia pode ser descrita em relação ao gênero dos artistas. Procuramos um perfil mais representativo possível dentro dos limites do projeto, prestando atenção ao gênero e à etnia do artista. Por exemplo, percebemos que os artistas negros eram todos masculinos e procuramos (com sucesso) convidar mais artistas negras a participar na antologia, com produções valiosas, mesmo assim a representação negra é muito restrita. Percebemos também pouca representação de produções literárias por indígenas e asiáticos, mas não conseguimos garantir uma produção mais significativa. No futuro, com acréscimo de novas produções literárias, esperamos um perfil ainda mais representativo de todas as raças.

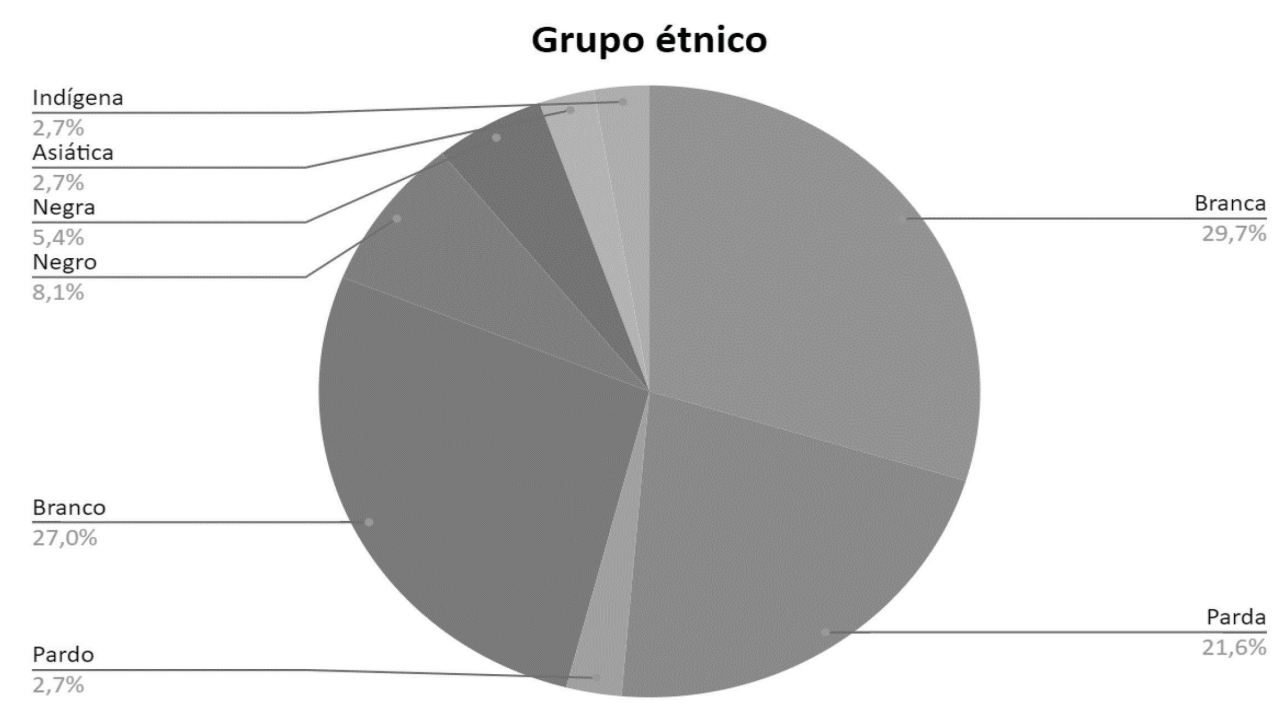

Gráfico 2: Etnias representadas

Fonte: elaboração das autoras (2020) 
A antologia foi criada no sul do Brasil em Santa Catarina, mas o nosso objetivo era contar com uma antologia representando o país inteiro, com produções dos artistas brasileiros de todas as regiões. Não conseguimos exemplos literários de cada estado, mas nos esforçamos para ter uma amostra abrangente e conseguimos produções literárias de 12 estados brasileiros. Esperamos no futuro incluir mais produções de produções de outros estados.

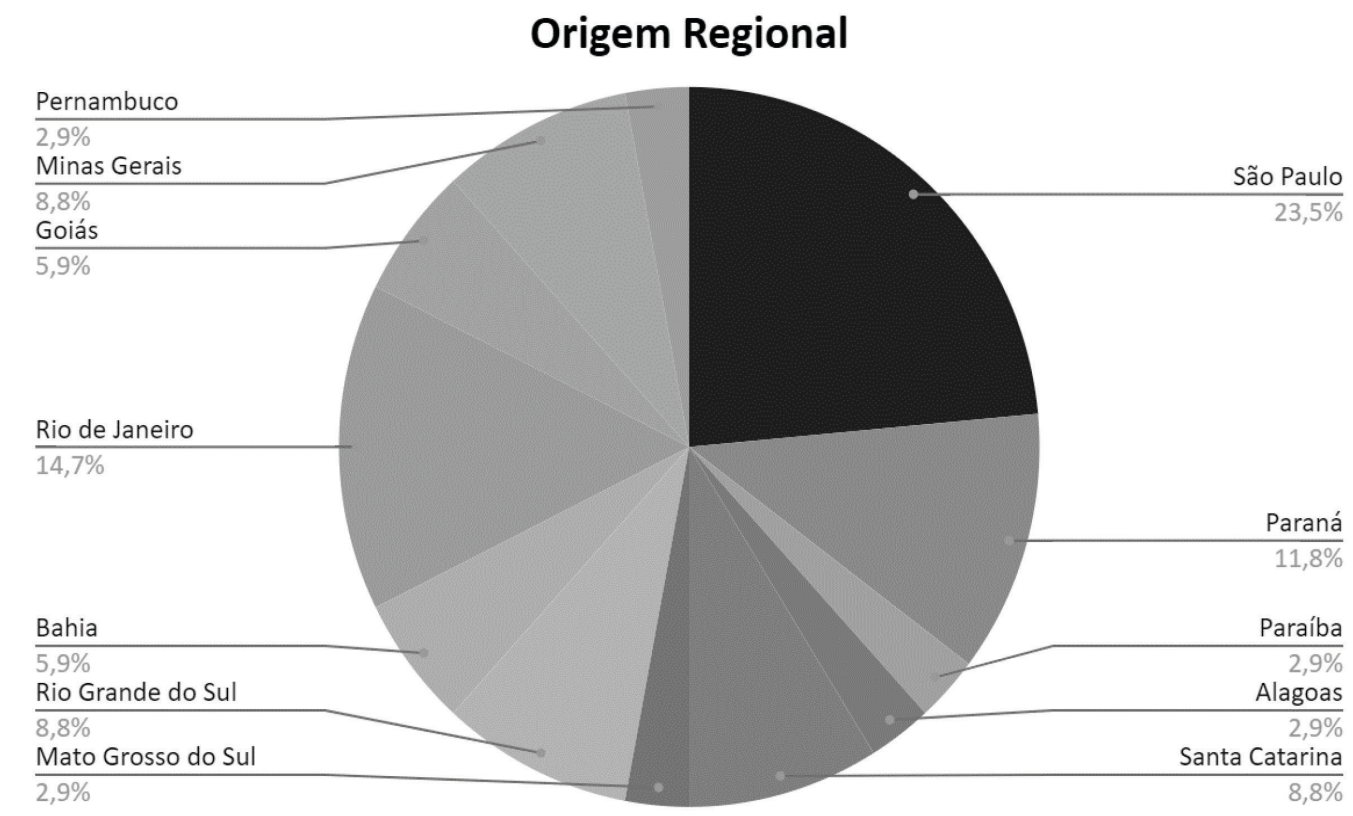

Gráfico 3: Estados brasileiros representados

Fonte: elaboração das autoras (2020)

Percebemos que a grande maioria dos artistas contam com formação para atuarem como ator ou poeta. Quase 60\% já fez algum curso e estudou para ser ator ou poeta. Esse é um grande avanço em comparação com muitos países, mas ainda 40\% não conta com formação e desenvolveram empiricamente suas habilidades criando as obras com base na experiência tradicional e cultural de participar na comunidade surda.

\section{Se formou como ator ou poeta}

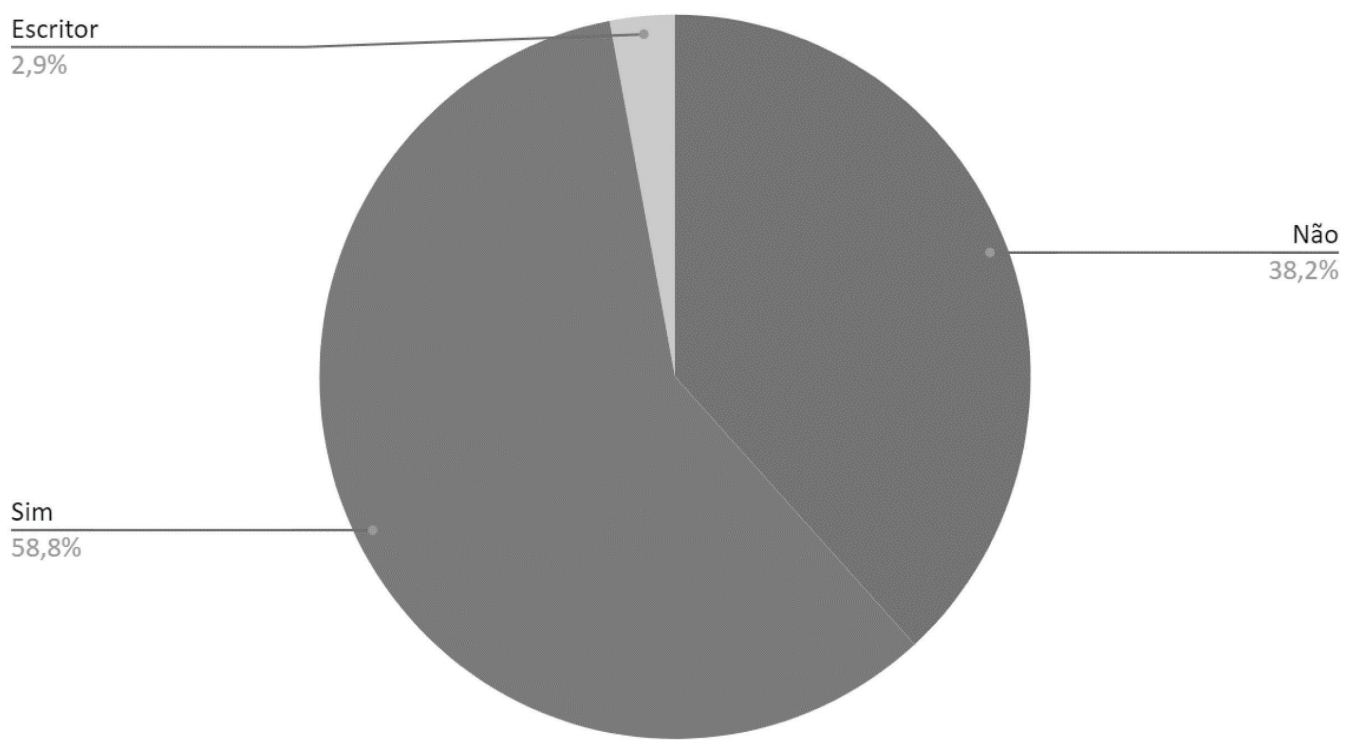

Gráfico 4: Formação para atuar como ator ou poeta

Fonte: elaboração das autoras (2020) 
Nossa antologia está destinada principalmente (embora não exclusivamente) aos professores. Vimos que $65 \%$ dos artistas atuam ou já atuaram como professor. Com isso, vemos que a tradição de literatura surda pode passar às próximas gerações dos surdos a partir do ensino.

\section{Se atua como professor}

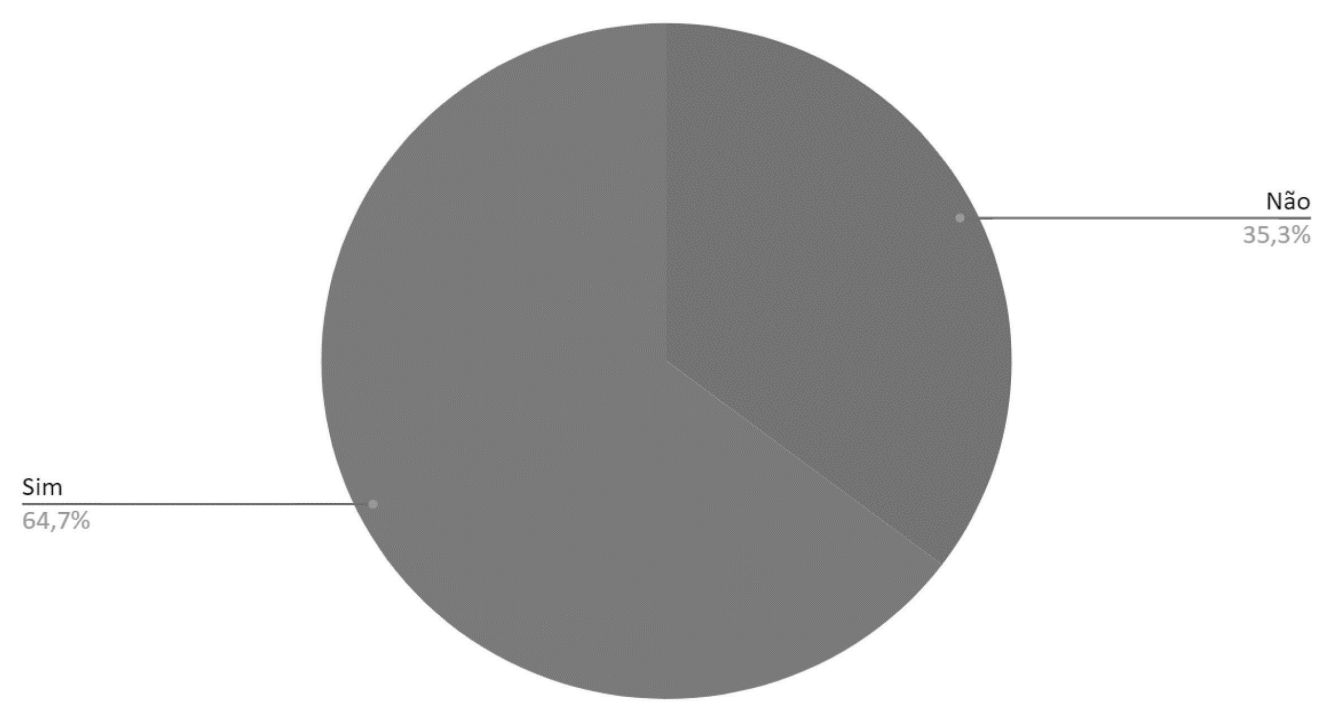

Gráfico 5: Se atua ou atuou como professor

Fonte: elaboração das autoras (2020)

A seguir, apresentamos a representação quanto aos gêneros literários e subgêneros integrantes da antologia. O gênero que apresenta maior incidência é o de poema dramático, seguido de poema dueto e poema homenagem.

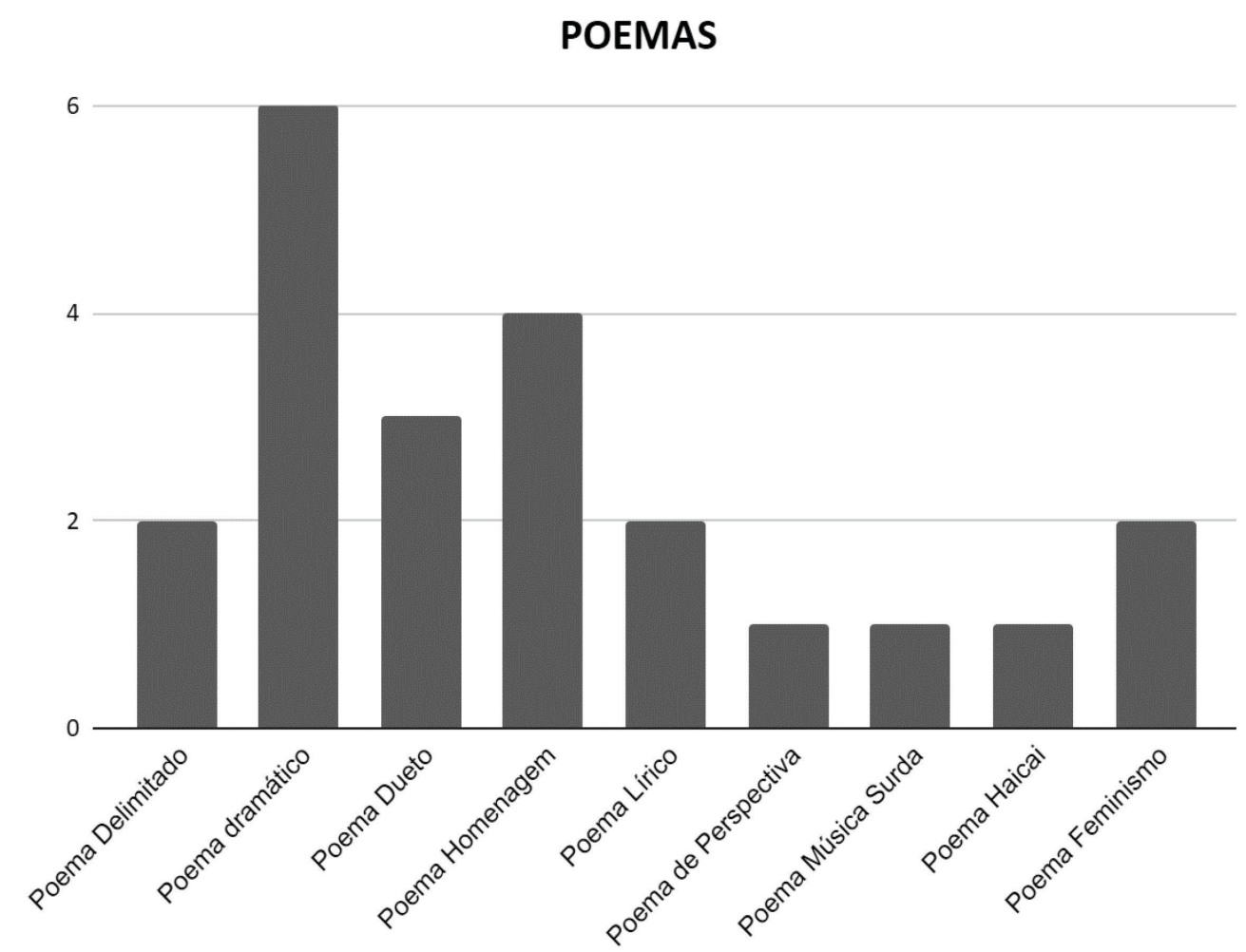

Gráfico 6: Gêneros literários e os subgêneros dos materiais poemas

Fonte: elaboração das autoras (2020) 
O gráfico 7 apresenta os tipos de contos de origem não surda, ou seja, contos que foram adaptados ou traduzidos de contos escritos originalmente em Português. Na sequência, o gráfico 8 apresenta os tipos de contos de origem surda, ou seja, que foram criados por surdos.

\section{CONTOS ORIGEM NÃO SURDA}

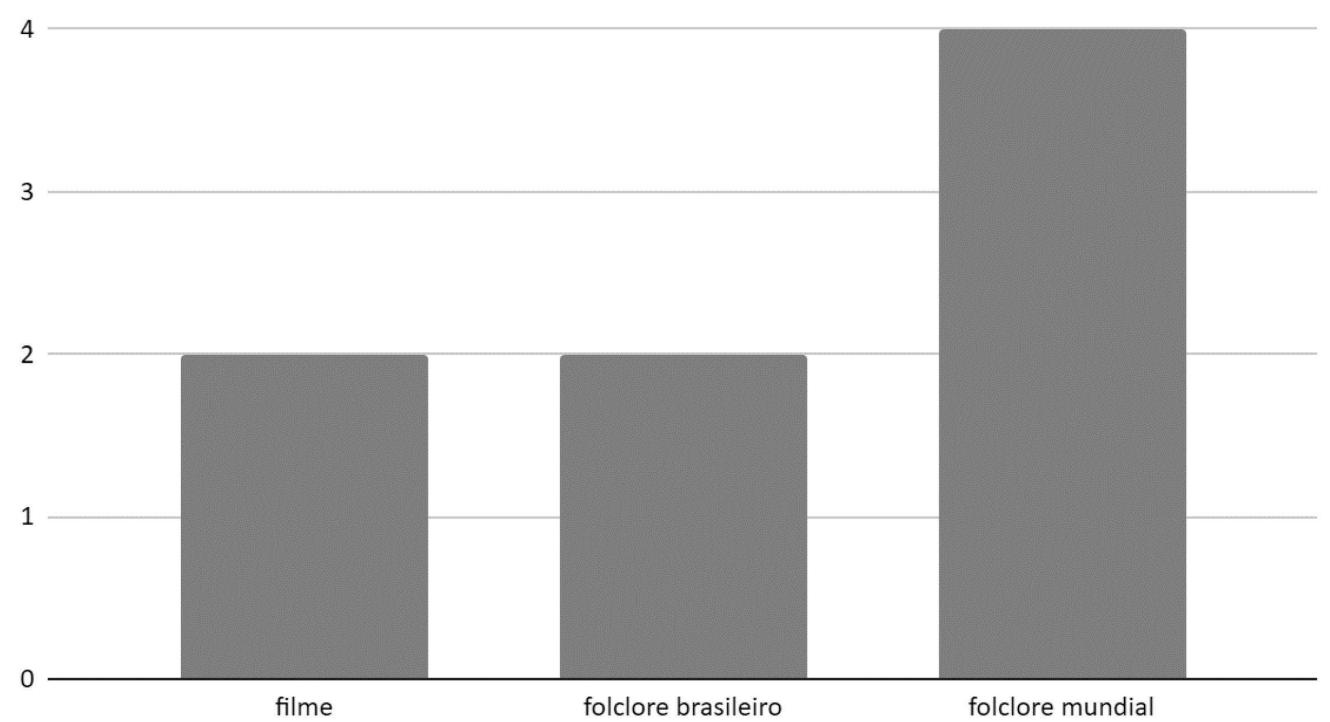

Gráfico 7: Contos de origem não surda

Fonte: elaboração das autoras (2020)

\section{CONTOS ORIGEM SURDA}

10

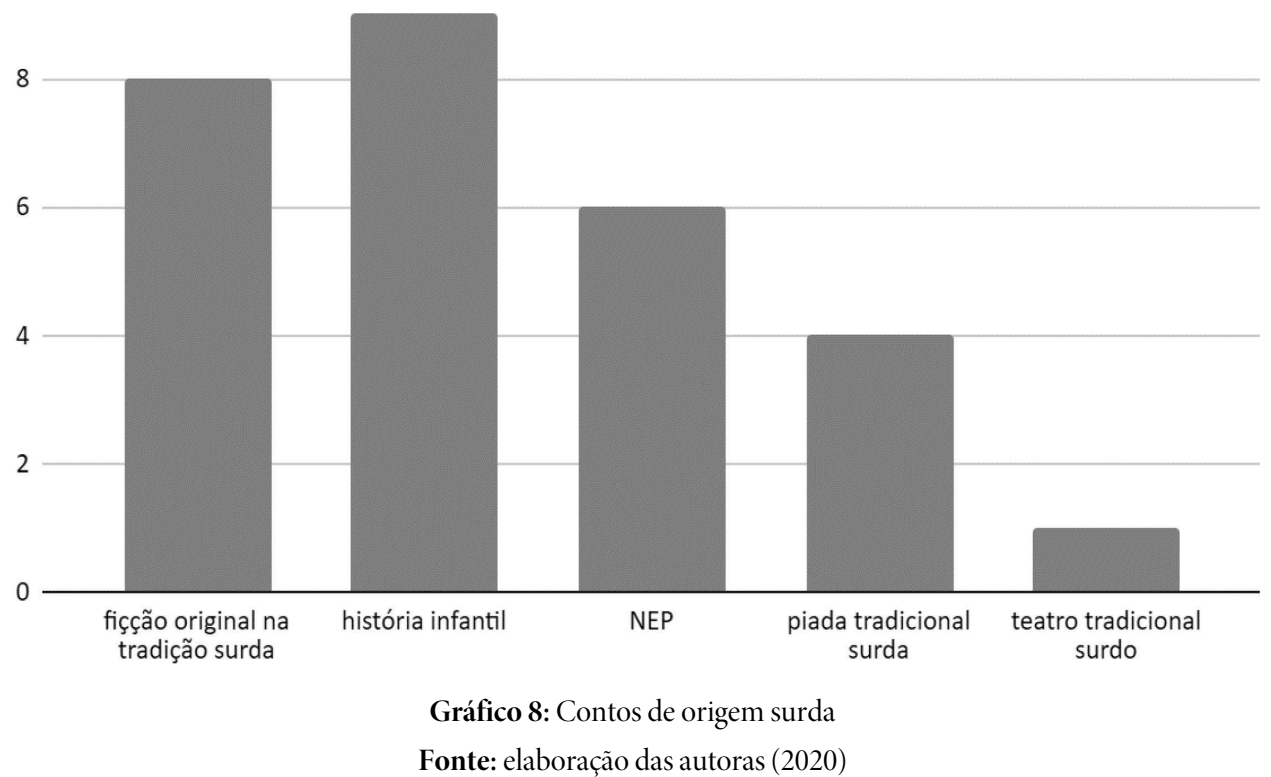

Apesar de haver 52 exemplos de produções literárias em Libras, produzidos por artistas surdos de diversos perfis sociais, esperamos que isso seja apenas o início das antologias literárias em Libras. 


\section{CONCLUSÃO}

Chegamos a uma antologia com uma seleção de obras em Libras memoráveis. A partir de todo o trabalho desenvolvido com as pesquisas realizadas, chegamos a 52 obras literárias em Libras. Concebemos uma ficha que compreendeu uma planilha com descrições que trazem elementos de análise literária de produções em Libras feitas por surdos com obras de origem surda e obras adaptadas ou traduzidas.

O material disponibilizado passa a servir de base e referência da Literatura em Libras, englobando vários estados do território nacional. Os registros regionais evidenciam características culturais locais caracterizando uma antologia de âmbito nacional.

A originalidade desta pesquisa fica caracterizada pelo processo de sua constituição que foi sendo determinada ao longo de sua constituição. Novas categorias foram criadas na medida em que nos deparamos com novas obras com suas características específicas. Procuramos honrar cada uma delas ao propor novas interpretações de registro e categorização, mas todas as descrições continuam sendo interpretações que partem da nossa perspectiva e podem ser criativamente reorganizadas. O fato de ser um dos primeiros trabalhos desta natureza faz com que sua forma represente iniciativas de organização literária que poderão ser aprimoradas em antologias futuras.

Decidimos separar as obras de origem surda das obras de origem não surdas porque percebemos diferenças nas temáticas e nas formas criativas de produção. Fizemos várias discussões em paralelo buscando registros filmados e realizando levantamentos. As obras disponibilizadas nesta antologia integram o Portal de Libras que é um espaço de domínio público, organizado pela Universidade Federal de Santa Catarina, Departamento de Libras, Programas de Pós-Graduação em Linguística e Estudos da Tradução, em parceria com o Instituto Federal de Santa Catarina, Unidade Bilíngue, Câmpus Palhoça.

A Antologia Literária em Libras está disponível como referência da Literatura Surda tanto para fins de pesquisa, como para ensino e lazer. Todos os interessados podem acessá-la para desfrutar das obras selecionadas e disponibilizadas por meio de produções em Libras. As famílias de surdos também podem aproveitar para "ler", ou seja, "assistir" as obras para os seus filhos surdos. Este material apresenta várias possibilidades de uso podendo ser acessado livremente para diferentes fins.

\section{AGRADECIMENTOS}

Este trabalho foi possível pelos recursos do Conselho Nacional de Desenvolvimento Científico e Tecnológico - CNPQ (\# 440337/2017-8).

\section{REFERÊNCIAS}

A ARTE DE SINALIZAR. Disponível em: https://www.ufrgs.br/artedesinalizar. Acesso em: 02 fev. 2021.

ANTOLOGIA DA POÉTICA EM LÍNGUA DE SINAIS BRASILEIRA. Disponível em: https://antologiaslibras.wordpress.com. Acesso em: 02 fev. 2021.

BAHAN, B. 'Face-to-face tradition in the American Deaf community. In: BAUMAN, H-D.; NELSON, J.; ROSE, H. (org.). Signing the body poetic. California: University of California Press, 2006. p. 21-50.

BARROS, R. O.; VIEIRA, Saulo Zulmar. The Relationship between Text and Image on Literary Productions in Libras. Sign Language Studies, n. 20, n. 3, Spring 2020, p. 392-410.

BARROS, Thatiane do Prado. Experiência de tradução poética de português/libras: três poemas de Drummond. Dissertação (Mestrado em Estudos da Tradução) - Universidade de Brasília, Brasília, 2015. 
BERGSON, H. O riso: ensaio sobre a significação do cômico. Tradutor, N. Caixeiro. Rio de Janeiro: Zahar Editores, 1983.

BOSSE, T. O. H. Literatura Surda no currículo das escolas de surdos. Tese (Doutorado em Educação) - Programa de Pós-Graduação em Educação, Universidade Federal de Rio Grande do Sul, Porto Alegre, 2019.

CAMPOS, K. de A. Literatura de cordel em Libras: os desafios de tradução da literatura nordestina pelo tradutor surdo. 2017. Dissertação (Mestrado em Tradução) - Programa de Pós-Graduação em Estudos da Tradução da Universidade Federal de Santa Catarina, Florianópolis, 2017.

CARTER, R. 2013. Made by Hand. 2013. DVD. Disponível em: www.bslpoetry.co.uk. Acesso em: 02 fev. 2021.

CASTRO, N. P. Literatura em LSB, LSB vídeo (DVD). Rio de Janeiro: Editora Abril e Dawn Sign Press, 1999.

CASTRO, N. P. A tradução de fábulas seguindo aspectos imagéticos da linguagem cinematográfica e da língua de sinais. 2012. Dissertação (Mestrado em Estudos da Tradução - Programa de Pós-Graduação em Estudos da Tradução, Universidade Federal de Santa Catarina, Florianópolis, 2012.

CENTRO DE EDUCAÇÃO PARA SURDOS (CES) - Rio Branco. Disponível em: https://www.youtube.com/playlist?list=PLBCE1E35CE2121DC8. Acesso em: 02 fev. 2021.

CIRILLIO, N. Anthologizing the Caribbean, or, Squaring Beaches, Bananas and Nobel Laureates. In: DI LEO, J. (ed.). On anthologies: Politics and Pedagogy. Lincoln: University of Nebraska Press, 2004. p. 222-246.

CLARK, J. L. (ed.). Deaf American Poetry. Washington DC: Gallaudet University Press, 2009.

CORDEL EM LIBRAS. Disponível em: https://www.youtube.com/channel/UCnawbM63PmSZpPnNWktq7AA. Acesso em: 02 fev. 2021.

CORPUS DE LIBRAS. Disponível em: http://www.corpuslibras.ufsc.br/dados. Acesso em: 02 fev. 2021.

CULTURA SURDA. Disponível em: https://culturasurda.net/ Acesso em: 02 fev. 2021.

DI LEO, J. Analyzing anthologies. In: DI LEO, J. (ed.). On anthologies: politics and pedagogy. Lincoln: University of Nebraska Press. 2004. p.1-27.

DOWNING, D. Theorizing the discipline and the disciplining of theory. In: DI LEO, J. (org.). On anthologies: politics and pedagogy. Lincoln: University of Nebraska Press, 2004. p. 342-370.

EMMERIK W. Poezie in Gebarentaal 1. Amsterdam: Het Komplex. 1995. Vídeo e DVD.

EMMERIK, W. Bevogen. 2005. Disponível em: http://www.geelprodukt.nl/motioning.html.. Acesso em: 02 fev. 2021.

FESTIVAL DE FOLCLORE SURDO 2014. Disponível em: https://repositorio.ufsc.br/handle/123456789/130149. Acesso em: 02 fev. 2021.

FESTIVAL DE FOLCLORE SURDO 2016. Disponível em: https://repositorio.ufsc.br/handle/123456789/172842. Acesso em: 02 fev. 2021. 
FESTIVAL DE FOLCLORE SURDO. 2018. Disponível em: https://repositorio.ufsc.br/handle/123456789/172842. Acesso em: 02 fev. 2021.

GIURANNA. R.; GIURANNA, G. Seven Poems in Italian Sign Language (LIS). Produzido por Rome: Graphic Service, Istituto di Psicologia, Consiglio Nazionale delle Ricerche, 2000. DVD.

GRAYBILL, P. Poetry in motion. Burtonsville, MD: Sign Media Inc. 1990.

HESSEL, C.; ROSA, F.; KARNOPP, L. Cinderela surda. Canoas: ULBRA, 2003.

HESSEL, C.; ROSA, F.; KARNOPP, L. Rapunzel surda. Canoas: ULBRA, 2003.

KARNOPP, L. Produções culturais em língua brasileira de sinais (Libras). Letras de Hoje, Porto Alegre, v. 48, n. 3, p. 407-413, 2013.

KARNOPP, L.; BOSSE, R. H. Mãos que dançam e traduzem: poemas em língua brasileira de sinais. Estudos de Literatura Brasileira Contemporânea, Brasília, n. 54,p. 123-141, 2018.

KARNOPP, L.; KLEIN, M.; LUNARDI-LAZZARIN, M. L. (org.). Cultura surda na contemporaneidade. Canoas: Editora ULBRA, 2011.

KARNOPP, L.; SILVEIRA, C. H. Humor na literatura surda. Educar em Revista, Curitiba; Editora UFPR, Edição Especial, n. 2 , p. 93-109, 2014.

KLAMT, M. M. O ritmo na poesia em língua de sinais. Dissertação (Mestrado em Linguística - Programa de Pós-graduação em Linguística, Universidade Federal de Santa Catarina, , Florianópolis, 2014a.

KLAMT, M. M. Sonoridade visual e sinalização artística em Língua Brasileira de Sinais. 2018. Tese (Doutorado em Linguística) Pós-Graduação em Linguística, Universidade Federal de Santa Catarina, Florianópolis, 2018.

KLAMT, M. M. Tradução comentada do poema em língua brasileira de sinais "Voo sobre rio". Revista Belas Infiéis, v. 3, n. 2, p. 107 $123,2014 b$.

KRENTZ, C. (org.). A mighty change: an anthology of deaf american writing 1816-1864, Washington,D.C.: Gallaudet University Press, 2000.

LEITCH, V. Ideology of Headnotes. In: DI LEO, J. (org.). On anthologies: politics and pedagogy. Lincoln: University of Nebraska Press, 2004. p. 373-383.

LIBRANDO. Disponível em: https://librando.paginas.ufsc.br. Acesso em: 02 fev. 2021.

LIBRAS. Portal de Libras. Disponível em: https://portal.libras.ufsc.br. Acesso em: 25 jan. 2021.

LIBRAS. Portal de Libras. Disponível em: https://libras.ufsc.br. Acesso em: 25 abr. 2020.

LUCZAK R. (org.). Eyes of desire, a deafgay \& lesbian reader. New York: Alyson Publications, 1993.

MACHADO, F. de A. Simetria na poética visual na Língua de Sinais Brasileira. 2013. Dissertação (Mestrado em Estudos da Tradução) - Programa de Pós-Graduação em Estudos da Tradução, Universidade Federal de Santa Catarina, Florianópolis, 2013. 
MACHADO, F. Poesia Árvore de Natal. Rio de Janeiro: LSB vídeo. 2005. DVD.

MACHADO, F.de A. Antologia da poética de Língua de Sinais Brasileira. 2017. Tese (Doutorado em Estudos da Tradução) Programa de Pós-Graduação em Estudos da Tradução, Universidade Federal de Santa Catarina, Florianópolis, 2017.

MÃOS AVENTUREIRAS. Disponível em: https://www.ufrgs.br/maosaventureiras/. Acesso em: 02 fev. 2021.

MÃOS LITERÁRIAS. Disponível em: https://www.youtube.com/channel/UCAQnpQwKtOtu5wx5jVyR9KA/playlists. Acesso em: 02 fev. 2021.

MARQUEZI, L. Literatura surda: o processo da tradução e transcrição em SignWriting. Dissertação (Mestrado em Estudos da Tradução) - Programa de Pós-Graduação em Estudos da Tradução, Universidade Federal de Santa Catarina, Florianópolis, 2018.

MAZZA, C. Finding the Chic in Lit. In: DI LEO, J. (ed.). On Anthologies: Politics and Pedagogy. Nebraska: University of Nebraska Press, 2004. p. 155-169.

MILES, D. Bright memory. Doncaster: British Deaf History Society, 1998.

MILES, D. Gestures: Poetry in Sign Language. Northridge, CA: Joyce Motion Picture Co, 1976.

MONTGOMERY, G. (org.). Language for the eye: anthology of deaf writing and publishing. Edinburgh: Scottish Workshop Publications, 1996.

MOURĀO, C. H. N. A fábula da Arca do Noé. Ilustrações Cathe de León. Porto Alegre: Cassol, 2014.

MOURÃO, C. H. N. Literatura surda: experiência das mãos literárias. 2016. Tese (Doutorado em Educação) - Programa de PósGraduação em Educação, Universidade Federal do Rio Grande do Sul, Porto Alegre, 2016.

MOURÃO, C. Literatura surda: produções culturais de surdos em língua de sinais. In: KARNOPP, L.; KLEIN, M.; LUNARDILAZZARIN, M. L. (org.). Cultura Surda na contemporaneidade. Canoas: Editora ULBRA, 2011. p. 71-90.

MOURÃO, C.; KLEIN, A. As luvas mágicas do Papai Noel. Adaptação Cathe de Leon, Léis Cassol. Ilustrações Gisele Federissi Barcellos. Porto Alegre: Cassol, 2012.

NATHAN LERNER, M.; FEIGEL, D. The heart of the hydrogen jukebox. New York: Rochester Institute of Technology, 2009. DVD. O SOM DAS PALAVRAS - antologia literária. Rio de Janeiro: Litteris Ed., 2003.

OLIVEIRA, R. Meus sentimentos em folhas. Rio de Janeiro: Editora Litteris. 2005.

PANARA, R.; TARAS, D. B.; MCFARLANE, J. H. (org.). The silent muse: an anthology of prose and poetry by the Deaf Gallaudet College Alumni Association Washington:. [s. n.], Washington, 1960.

PARAN, A. The role of literature in instructed foreign language learning and teaching: An evidence-based survey. Language Teaching, v. 41, n. 4, p. 465-496, 2008.

PEIXOTO, J. O registro da beleza nas mãos: a tradição de produções poéticas em Língua de Sinais no Brasil. 2016. Tese (Doutorado em Letras) - Programa de Pós-Graduação em Letras da Universidade Federal da Paraíba, João Pessoa, 2016.

PEREIRA, S. Piada em Libras. [S.l.: s.n.], 2009. DVD. 
RAMOS, C. R. Tradução cultural: uma proposta de trabalho para surdos e ouvintes. Reflexões sobre trabalho de tradução de textos da literatura para a LIBRAS, realizado na Faculdade de Letras da UFRJ entre os anos de 1992 a 2000. Rio de Janeiro: Arara Azul, 2000 .

RENNIE, D. Poetry in motion. Burtonsville, MD: Sign Media Inc. 1990. DVD.

REPOSITÓRIO DA UFSC. Disponível em: https://repositorio.ufsc.br/handle/123456789/176559.

RESENDE, L. S. Tradução teatral: produzindo em Libras no teatro surdo. 2019. Dissertação (Mestrado em Estudos de Tradução) Universidade de Brasília, Brasília, 2019.

ROSA, F.; KARNOPP, L. Adão e Eva. Canoas: ULBRA, 2005.

ROSA, F.; KARNOPP, L. Patinho surdo. Canoas: ULBRA, 2005.

ROSE, Heidi. The poet in the poem in the performance: the relation of body, self, and text in ASL literature. In: BAUMAN, H; NELSON, J; ROSE, H (org.). Signing the Body Poetic. California: University of California Press, 2006. P. 130-146.

RYAN, S. 'Let's Tell an ASL Story'. In: GALLAUDET UNIVERSITY COLLEGE FOR CONTINUING EDUCATION. Conference Proceedings... Washington, D.C.: Gallaudet University Press. 1993.

SCOTT, P. BSL Sign Poetry. Coleford, Glos: Forest. 2006. DVD.

STREMLAU, T. M. (org.). The Deaf Way II Anthology: A literary collection by deaf and hard of hearing writers. Washington DC: Gallaudet University Press, 2000.

SUTTON SPENCE, R. Literatura em Libras. Rio de Janeiro: Arara Azul, Editora Arara Azul. No prelo.

SUTTON SPENCE, R. Literatura surda feita por mulheres. In: SILVA, A. et al. (org.). Literatura e artes, teoria e crítica feitas por mulheres. Instituto Brasil Multicultural de Educação e Pesquisa - IBRAMEP: Campos dos Goytacazes , 2019. p142-166.

SUTTON-SPENCE, R. Teaching Sign Language Literature in L2/Ln Classrooms. In: ROSEN, R. (org.). Routledge handbook of sign language pedagogy. Abingdon: Routledge, 2020. p. 233-246.

SUTTON-SPENCE, R.; KANEKO, M. Introducing sign language literature: creativity and folklore. Basingstoke: Palgrave Press, 2016.

TV INES. Disponível em: http://tvines.org.br/?page id=12. Acesso em: 02 fev. 2021.

VALLI, C. Poetry in motion. Burtonsville, MD: Sign Media Inc. 1990.

VIEIRA, S. A produção narrativa em Libras: uma análise dos vídeos em Língua Brasileira de Sinais e da sua tradução intersemiótica a partir da linguagem cinematográfica. 2016. Dissertação (Mestrado em Estudos da Tradução) - Programa de Pós-Graduação em Estudos da Tradução, Universidade Federal de Santa Catarina, Florianópolis, 2016.

\section{() $\circledast \circledast$}

